\title{
The Financial Crisis, Financial System Instability and Monetary Transmission Mechanism
}

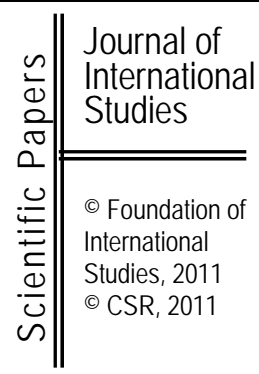

PhD Marek Zwolankowski

Department of Finance

Faculty of Economics and Management

University of Szczecin

zwolankowski1@wp.pl

\begin{abstract}
The current financial crisis is also a crisis of cognition. Erroneous strategy of central banks and accommodative monetary policy (primarily of the Fed) have become causes of distortion of the information function of financial assets' prices. Excessive - in favourable monetary conditions expansion of the global financial system has increased the complexity (ergo non-transparency of information) of financial operations and investment strategies.
\end{abstract}

Submitted: September, 2011 $1^{\text {st }}$ revision: October, 2011 Accepted: November, 2011

Keywords: Financial Crises, Monetary Transmission Mechanism.

JEL classification: E32, E58, G01.

\section{Introduction}

One of the features of the modern financial system is the complexity of structures and such uncontrolled dynamics, that in consequence it is objectively prone to loss of stability. The financial crisis has demonstrated that today's financial systems have been "threatened by complexity", and the world of finance has reached a point where "hidden structures" appeared (Lipshaw, 2009, p. 299). Therefore one can formulate a hypothesis about structural and not only business cycle-related causes of the global financial crisis, as:

1. the increased complexity of information and extreme cases of information asymmetry have reduced the effectiveness of the financial regulation process;

2. the financial crisis has largely become a crisis of cognition.

It should have been foreseen that in the conditions of major disturbances of the environment (vide financial crisis). "[...] discords between successive pieces and layers of information will present many problems of survival (underlined by M.Z.) and determine many directions for change" (Bateson, 1980, p. 37). In the debate on the nature of the current financial crisis it is worth to expose the threads bringing up the existence of the limits of economic knowledge, introducing the notion of "economics of imperfect knowledge" and accepting the well-known statement of the Governor of the Bank of England, M. King, arguing that "...our understanding of the economy is incomplete and constantly evolving..." (Frydman, Goldberg, 2009, p. 5 and 21-22).

\section{The original cause of the global financial crisis}

We propose that the effectiveness and stability of the financial system are its two 
equivalent attributes. The overuse - prior to the outbreak of the financial crisis - of the effectiveness potential of the financial system has led to loss of its stability. Against this background a hypothesis appears about the special role of the monetary policy of central banks in the disturbance of the global financial system. The mandate to shape monetary stability and the mandate to protect financial stability should have equal weights in any bank's activities. In numerous studies of the Fed's monetary policy an argument appears that excessive favouring of the objective of low and controlled inflation has contributed to the disintegration of the structures of the U.S. financial system" (Bates and Vaugirard, 2009, p. 153). As a result of exceptionally favourable monetary conditions the global financial system has experienced the consequences of "overshoot" in the meaning that was given to this term in the Club of Rome documents; "overshoot" means an unintended breach of the limits of growth. In the conditions of low and stable interest rates the mortgage market has exceeded the limits of growth. Credit overexpansion has caused an imbalance not just locally. A building-up process of an imbalance in the entire financial system has started (Fig. 1), as:

1. low cost of hedging encouraged an uncontrolled rise in trade volumes on the derivatives market (primarily credit derivatives);

2. financial institutions, especially banks, received a strong incentive towards a strategy of increasing their exposure to risk and overusing financial leverage.

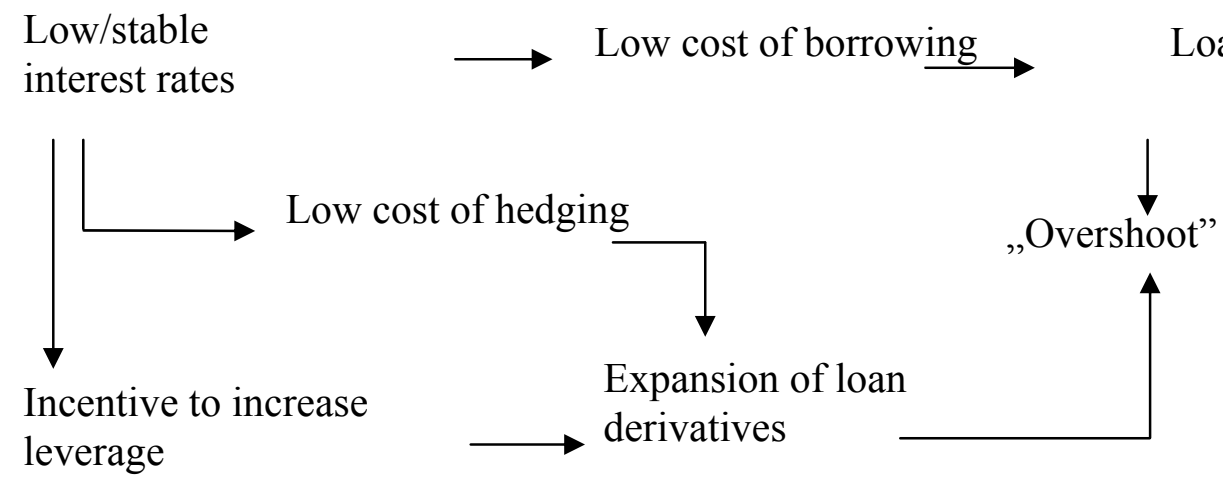

Fig. 1. Low interest rates and breaching the limits of growth ("overshoot"). Source: Own work

The scale and rate of increasing systemic imbalance made it impossible to continue to promote the idea that we were facing a well-known phenomenon of recurring crises, reflecting "... a fundamental procyclicality in the system, characterised by extensive exposure to risk and extensive leverage in good times and sudden withdrawal from risk and reducing leverage in bad times" (Cohen, Remolona, 2009, p. 7). In other words, we are dealing with an archetypal example of financial instability, with potentially dangerous macroeconomic consequences following the build-up of financial imbalances in "good times" in the form of overstretched balance sheets (Borio, 2008, p. 1).

The first signs of weakness on the subprime loan market started to appear between January and May 2007, when information was revealed about deteriorating mortgage loan quality indicators (default rate) (Jyske Markets, 21.11.2008, p. 1). Lower quality of loan portfolio resulted directly from worsening of conditions in the real estate market, i.e. falling prices. Banks' increased losses on loan operations usually leads only to banks' shrinking interest incomes, but also to erosion of equity indicators. Because the banking sector is strictly regulated (amongst others in the form of obligation to maintain capital adequacy - solvency ratio), the banks are subjected to pressure towards reducing financial leverage. In such circumstances - according to the logic of feedback - new macroeconomic consequences 
appear. Banks' reduced ability to offer new lending, increasing tightness in the loan market and lower propensity to borrow become factors of macroeconomic slowdown.

The macroeconomic perspective brings back the proposition of three cycles as fundamental causes of the current financial crisis. These are three interconnected cycles - in the housing market, the credit market and in real business activity (Igan, Kabundi, De Simone, Pinheiro, Tamirisa, 2009, p. 1).

The cycle in housing prices leads to a long-term credit cycle and business cycle, and during a long-lasting boom in the property market the households experience a higher level of wealth and propensity to higher spending. The changes in the real estate market and in the credit market are interlinked in both directions. On the one hand the wealth effect (high property prices) activates the demand for credit in other segments of the market - including the consumer loans market. In such circumstances, the banks respond with a higher credity supply, relaxing the loan procedures, as the market value of collateral increases. On the other hand, low cost of capital additionally activates speculative demand in the property market and expectations for sustaining the prices in that market in the future. In conclusion, the crisis in the U.S. mortgage market was caused by two gigantic, interlinked speculative bubbles bursting at the same time - one in the property market, the other in the credit market.

It is worth to recall here the financial accelerator model, developed by B. Bernanke and M. Gertler. In general it is a way to explain business cycle fluctuations, when good lending conditions and strong economy are mutually coupled (leading to a collapse). When explaining the sources of the current U.S. financial crisis, B. Bernanke reaches to this concept, using it to explain the impact on banks' balance sheets. Coherent with this direction of studying the roots and nature of the U.S. crisis, there is an approach exposing the fundamental relation in building (a contrario in losing) the macrostability of economic systems: financial markets' liquidity - central bank's monetary policy - credit cycle (Adrian, Song Shin, 2008, p. 1). The detailed assumptions constituting the methodological framework of the study, are as follows:

1. Banks increase the financial leverage during economic boom and reduce its level during economic slowdown;

2. From the point of view of managing the balance sheet structure, financial liquidity can be indirectly quantified by the rate of growth of balance sheet totals;

3. Maintaining too low interest rates for too long a period creates excessive liquidity, resulting in rising prices of property, stocks and other assets, and in consequence contributes to speculative bubbles forming in different markets.

The latter conclusion opens the problem of the sequence of the financial crisis, being the focal point of research on the loss of global financial stability. In the EBC research materials (Research Bulletin No. 7, June 2008) three stages of the financial crisis have been defined. First, the stage of fundamental sources of the crisis, related to the increasing imbalance on financial markets. Its dynamics was shaped by financial investors - acting with excessive propensity to take risks and the strategy of "search for profit". Second - the stage of appearance of tensions in the credit market in its broad spectrum. These tensions were generated not only by information coming from the subprime market. Some authors argue that from the global perspective, the U.S. subprime loan market is a niche market. In June 2007 news appeared that two hedge funds (run by Bear Stearns), investing in assets based on mortgage loans, were threatened with bankruptcy. That event started to change the optics of threat analysis - the disturbances started to go beyond the above mentioned market niche. Third, the stage of systemic crisis, that is the stage of appearance of systemic risk, attacking money markets critical to the system. It is therefore understandable that in many analyses of transmission of financial crisis impulses (between different economies and along the structures of national financial systems) the disturbances in the money market has been 
considered a phenomenon "exceeding the critical mass" of the crisis.

Assuming that the imbalance on the money market was the decisive situation, one can present the sequence of the global financial crisis in a different manner. Such a viewpoint can be observed in research inspired by the OECD (Wehinger, 2008, pp. 1-8), exposing "acceleration channels" of the impulses of financial crisis. In this methodology the following relationships have been distinguished: property market - securitization market - banks' balance sheets - interbank market - broad loan market. The presented cause-and-effect chain has been afterwards interpreted in the light of their broad consequences, in the form of:

1. sudden and deep drop of stock prices;

2. reorientation of financial investors and rebuilding of their investment portfolios (shift towards "safe havens", i.e. more interest in the bond market);

3. high volatility of prices of all financial assets;

4. coordinated actions by central banks aimed at rebuilding liquidity on money markets.

\section{Distorted monetary transmission mechanism}

The money market is the key medium of monetary transmission, and its stability is a prerequisite of an effective monetary policy of any central bank. Treating the monetary transmission mechanism as an important reference point in research on both causes and effects of the financial crisis, we ask the following question: had it already been modified earlier by long-term trends, or has it only been temporarily distorted by the financial crisis? A view exists that the strength of monetary transmission (strength of impulses from central banks) was enhanced a long time before the financial crisis by changes of long-term character: growing competition in the financial market, high level of debt among households, globalisation of the financial system (Cournede, Ahrend, Price, 2008, p. 2). On the other hand one should assume, however, that the financial crisis has not only temporarily distorted monetary transmission, but it also has also caused long-lasting implications for the way in which today's central banks influence the global economy.

The transparency and credibility of any central bank depends to a large extent on whether monetary impulses directed at banks and messages sent to the participants of economic life are coherent. With this background a hypothesis may be presented about distortion of the information function of the financial system as a consequence of erroneous, i.e. incoherent monetary policy of central banks (primarily the Fed). The U.S. central bank first maintained too low interest rates for too long, and then raised them too slowly and too late (Roubini, Mihm, 2011, p. 97). A low market interest rate is synonymous with significant flattening of its structure and lowering the risk premium, as a component of the cost of money. As a consequence, in borrowers' and investors' decisions in the securities' markets the underestimation of risk has become a repeated occurrence. Aggressive attitude towards risk was additionally fuelled by market players' expectations towards the long-term tendency of low interest rates. In general perception, in such conditions the Fed has created speculative bubbles, and then taken an asymmetrical position:

1. the bubbles will not be suppressed, as in practice they are dificult to define and control

2. the boom has to be counteracted, if it leads to bursting of the bubbles.

Concluding, an asymmetry of information appeared in relations between the central bank and the investor. The Fed was sending an incentive to borrow, and on the other hand it was not clear enough in communicating its second mandate (apart from monetary stability) of taking care of the stability of the entire financial system.

The investment euphoria also took over the so-called shadow banking system; "these newly established financial institutions preyed on cheap money and credit..." (Roubini, Mihim 2011, pp. 84 and 37-38). The shadom banking system is institutionally varied and it covers 
such institutions as hedge funds, special structured investment vehicles, or money market funds. In many aspects of financial brokerage functions these institutions are similar to banks, with one difference - they remain outside the financial regulation territory. The institutions of the shadow banking system have also built their operational strategies in a different way, as:

1. they used high leverage with sources of financing other than deposits,

2. they offered long-term loans, which were engaged in low-liqudity assets,

3. they borrowed "short-term", on very liquid markets.

In particular the investment strategies of these institutions were based on involvement in the securitization market and thus creating a large part of the liquidity in the U.S. financial system. Their expansion and competition with banks has deeply transformed the nature of financial intermediation in the USA (Pozsar, Adrian, Ashcraft, Boesky, 2010, p. 2). As a consequence, this specific system of parallel banking has distorted the traditional monetary transmission mechanism. Firstly, remaining without access to central bank's liquidity, these institutions have started to provide liquidity to the money market themselves. A large share of the money market has remained outside the system of regulatory influence of the Fed. It is well known that regulating the liquidity on the money market is the domain of every central bank and a basis for "translation" of monetary decisions regarding the level of official shortterm interest rates on other financial assets' prices. Secondly, the activity of shadow banking institutions has had significant impact on the process of development of speculative bubbles and on the significant separation of financial assets' market prices from their fundamental value. The dynamic increase in assets of financial institutions operating outside the traditional banking system corresponds with the opening statement on the expansion of "hidden structures". Non-transparent financial institutions, existing beyond regular control and offering non-transparent instruments, have increased the complexity of the U.S. financial system. In such conditions the Fed's efficiency has become limited, especially in shaping the financial stability.

The tensions in the U.S. money market, distorting the monetary transmission mechanism, could have also been caused by the tendency of large increase of balance sheet totals in the U.S. banking system. The largest banks enjoy the status of being "systemimportant", due to the scale of mutual involvement in the interbank market and the potential to trigger the domino effect in the process of erosion of financial liquidity of the entire banking sector. It is worth noting that between 2002 and 2008 the largest banks (assets exceeding USD $10 \mathrm{bln}$ ) have raised their share in total assets of the entire sectory by almost 10 percentage points (from $68,7 \%$ in 2002 to $78,2 \%$ in 2008 ).

Theory provides much evidence to the argument that large, system-important banks, can resist monetary impulses generated by central banks. They tend to overuse their position in the financial system and act by the logic of moral hazard (temptation of abuse). In this latter aspect another proposition appears, that a new chapter in the global financial crisis was opened on the day of 15 September 2008 - the day of filing for bankruptcy protection of the U.S. investment banking giant, Lehman Brothers. The doctrine of being "too big to fail" or "too interlinked (on the interbank market) to fail" has ceased to work. After that event almost all market indices demonstrated a loss of confidence in the markets and financial institutions. For the first time since 2002 the main U.S. stock market fell by more than $4 \%$.

\section{Conclusion}

A synonym of the current financial crisis is the loss of stability in the global financial system, in its institutional and market aspect. The consequences of the financial crisis - in a synthetic approach - can be defined bearing in mind the three attributes of financial stability, i.e.: 
1. the financial system's ability to effectively allocate capital,

2. adequate valuation of financial instruments and proper risk assessment,

3. the ability of financial institutions (primarily banks) to absorb the consequences of shock without external assistance.

Easy access to bank loans and excessive propensity to risk - as a consequence of accommodative ("relaxed") monetary policy of central banks - have distorted the allocation of capital. Deep imbalance in the financial market was caused by an expansion of innovative financial instruments, complex in construction and with a risk profile difficult to detect. Excessive and uncontrolled dynamics in the securitization transactions market was derived from the strategy of shadow banking institutions - non-transparent players offering nontransparent products. The banks, in the conditions of a deep "narrowing of the money market", loss of confidence and large drops in stock prices, have lost their ability to absorb losses. The common axis of those processes of imbalance is the phenomenon of the information function of the financial market. The analysis of the monetary transmission mechanism leads to the statement that a large part of the blame related to that phenomenon can be put on the central banks' errors.

\section{References}

Adrian, T., Song Shin H. (2008), Liquidity, Monetary Policy, and Financial Cycles, Current Issues in Economics and Finance, vol. 14, nr 1, January/February, Federal Reserve Bank of New York, p. 1.

Bates, S., Vaugirard, V. (2009), Monetary Transmission Channels Around the Subprime Crisis: The US experience, Global Economy \& Finance Journal, Vol. 2 No. 2 September, p. 153.

Bateson, G. (1996), Umyst i przyroda, Państwowy Instytut Wydawniczy, Warszawa.

Bernanke, B.S. (2007), At the Credit Chanel on Monetary Policy in the Twenty - first Century Conference, Federal Reserve Bank of Atlanta, Atlanta, Georgia. June 15, p. 1-6.

Borio, C. (2007), The financial turmoil of 2007: a preliminary assesment and some policy considerations, BIS Working Papers No 251, March X, p. 1.

Cassola, N., Drehmann, M., Hartmann, P., Lo Duca, M., Schleicher, M. (2008), A research perspektive on the propagation of the credit market turmoil, Research Bulletin No 7, June, EBC, p. 2-5.

Cohen, B., Remolona, E., The Unfolding Turmoil of 2007-2008: Lesons and Responses. Lessons from the Financial Turmoil of 2007 and 2008, Reserve Bank of Australia, p. 7.

Cournede, B., Ahrend, R., Price, R. (2008), Have Long-term Financial Trends Changed Transmission of Monetary Policy?, OECD Economics Department Working Papers No. 634.

Frydman, R., Goldberg, M.D. (2009), Ekonomia wiedzy niedoskonatej, Wydawnictwo Krytyki Politycznej, Warszawa.

Igan, D., Kabundi, A., De Simone, F.N., Pinheiro, M, Tamirisa, N. (2009), Three Cycles: Housing, Credit, and Real Activity, IMF Working Paper WP/09/231, October, p. 3-5.

Lipshaw, J.M. (2009), The Epistemology of the Financial Crisis: complexity, causation, law, and judgment, Southern California Interdisciplinary Law Journal, Vol 19, No. 2, Suffolk University Law School Legal Studies Research Paper 09-30, August 25, pp. 229-301.

Pozsar, Z., Adrian, T., Ashcraft, A., Boesky, H. (2010), Shadow Banking, Federal Reserve Bank of New York Staff Reports, Staff report no. 458, July.

Roubini, N., Mihim, S. (2011), Ekonomia kryzysu, Oficyna Wolters Kluwer business, Warszawa. 
The Global Financial Crisis. The financial crisis step by step. Jyske Markets, 21.11.2008, p. 1.

Wehinger, G. (2008), Lessons from the Financial Market Turmoil: Challenges ahead for the Financial Industry and Policy Makers, Financial Market Trends, OECD, p. 1-8. 